\title{
Pengaruh Penggunaan WhatsApp Messenger Sebagai Mobile Learning Terintegrasi Metode Group Investigation Terhadap Kemampuan Berpikir Kritis
}

\author{
Sulistyaning Kartikawati, Hendrik Pratama \\ Universitas PGRI Madiun \\ Madiun, 63118, Indonesia \\ Email:pratama@unipma.ac.id
}

\begin{abstract}
Penelitian ini bertujuan untuk mengetahui perbedaan pengaruh penerapan metode Group Investigation (GI) dengan WhatsApp Messenger sebagai mobile learning terhadap kemampuan berpikir kritis peserta didik. Metode penelitian yang digunakan adalah penelitian eksperimental menggunakan desain control group pretest-posttest. Prosedur pengambilan sampel menggunakan teknik purposive samplingyang terdiri dari 17 peserta didik sebagai kelompok kontrol dan 17 peserta didik sebagai kelompok eksperimen. Kelompok eksperimen dengan perlakuan metode pembelajara Group Investigation terintegrasi media sosial WhatsApp Messenger sedangkan kelompok kontrol dengan perlakuan pembelajaran secara tatap muka biasa tanpa integrasi media sosial. Teknik pengumpulan data menggunakan metode observasi, dokumentasi, wawancara, angket, dan tes.Peneliti menggunakan t-test untuk membandingkan kelompok kontrol dan eksperimen yang ditinjau dari aspek kemampuan berpikir kritis pada tingkat alpha 0,05. Hasil pada aspek kemampuan berpikir kritis pada kelompok eksperimen lebih baik daripada kelompok kontrol. Desain pembelajaran yang dirancang meliputi tahap start, grouping, planning, presenting, organizing, investigating, evaluating, ending. Proses investigasi dalam kelompok melatih peserta didik untuk berpikir kritis
\end{abstract}

Kata Kunci : WhatsApp Messenger, Mobile Learning, Group Investigation, Kemampuan Berpikir Kritis

\section{Pendahuluan}

Kondisi pembelajaran di Program Studi Pendidikan Teknik Elektro IKIP PGRI Madiun membutuhkan konsep pembelajaran yang aktif, inovatif, kreatif, efektif, dan menyenangkan. Hal ini didasarkan pada karakteristik materi seperti elektronika dasar dan bahan listrik, dan fisika teknik yang menuntut mahasiswa menguasai teori sekaligus mampu mengaplikasikan secara riil. Hasil wawancara dengan mahasiswa menunjukkan bahwa metode pembelajaran didominasi dengan ceramah dan terlalu fokus pada teori tanpa disertai contoh aplikatif kurang disukai dan membosankan. Mahasiswa kurang dapat memahami konsep dan aplikasinya sehingga kemampuan berpikir kritisnya rendah. Hal tersebut diperkuat dengan kemauan membaca mahasiswa yang rendah karena lebih memilih bermain smartphone daripada membaca buku pelajaran.

Hasil evaluasi terhadap mahasiswa Pendidikan Teknik Elektro semester 2 tahun akademik 2015/2016 menunjukkan bahwa rata-rata hasil belajar mata kuliah Elektronika Dasar masih rendah $(66,26)$. Hasil tes dari 21 mahasiswa terdapat 1 siswa dengan kategori tidak lulus, 17 siswa kategori cukup, dan 3 siswa dengan kategori baik. Data tersebut menunjukkan bahwa proses pembelajaran mata kuliah Elektronika Dasar belum optimal.

Keterbatasan alat laboratoratorium yang tidak bisa memenuhi kebutuhan semua mahasiswa sehingga pada saat akan melakukan kegiatan eksperimen hasil yang diperoleh kurang 
maksimal. Mahasiswa harus bergantian menggunakan peralatan. Salah satu upaya pengajar yang sudah diterapkan adalah menggunakan video eksperimen sehingga mahasiswa mampu mempelajari lebih dalam terkait eksperimen yang dilakukan. Hasil angket terhadap 20 mahasiswa yang sudah mengikuti model pembelajaran dengan video, 17 orang (85\%) menunjukkan bahwa video dapat membantu mempelajari materi dengan mudah dan lebih menyenangkan. Sejalan dengan penelitian Hendrik (2016), penggunaan video yang berisi kegiatan eksperimen membuat penyampaian pembelajaran menjadi lebih menarik. Kemampuan psikomotorik dan kreatifitas siswa akan dilatih, dan pada akhirnya akan mempengaruhi prestasi belajar mahasiswa secara keseluruhan.

Mengacu pada kondisi tersebut, peneliti menerapkan metode pembelajaran menggunakan metode pembelajaran Group Investigation (GI) terintegrasi WhatsApp Mesengersebagai Mobile Learning(M-Learning). Berdasarkan penelitian Lillian Buus (2012), peran $M$ Learning mampu menciptakan suasana akademis yang kondusif karena mahasiswa bisa belajar dimanapun dan kapanpun. Implementasinya dalam pembelajaran mampu menghadirkan suasana belajar yang santai. Kedekatan emosional yang baik akan terbentuk seiring meningkatnya intensitas komunikasi melalui media sosial menjadikan banyaknya ide baru terkait pembelajaran yang diberikan.

Sejalan dengan penelitian yang dilakukan, Group Investigation (GI) merupakan metode pembelajaran yang salah satunya tujuannya untuk meningkatkan kemampuan berpikir kritis. Berpikir kritis merupakan kegiatan mental dalam mencermati suatu pertanyaan dan berpikir yang menekankan pembuatan keputusan tentang jawaban alternatif yang benar. Kemampuan tersebut harus dikembangkan pada siswa yang bermanfaat untuk memecahkan masalah yang terkait dengan pelajaran. Oleh karena itu kemampuan berpikir kritis hendaknya dikembangkan oleh pendidik untuk meningkatkan hasil belajar peserta didik. Model pembelajaran dirancang untuk membimbing mahasiswamendefinisikan masalah, mengeksplorasi berbagai masalah, mengumpulkan data yang relevan, mengembangkan, dan menguji hipotesis. Metode pembelajaran ini memiliki keunggunalan melatih peserta didik untuk membangun kemampuan berfikir secara mandiri dan kritis serta melatihnya dalam menyelesaikan suatu permasalahan dalam kelompok. Model pembelajaran GI menurut Slavin (2010:216-229) yaitu setiap tahapan dalam model pembelajaran tersebut mengarahkan peserta didik untuk berpikir kritis. Oleh karena itu, dalam penelitian ini kemampuan berpikir kritis menjadi fokus kajian untuk ditingkatkan.

\section{Metode Penelitian}

Penelitian ini dilakukan di Program Studi Pendidikan Teknik Elektro di Universitas PGRI Madiun Jl. Setia Budi 85 Madiun 63118. Populasi dalam penelitian ini adalah peserta didik semester 2 (dua) di Program Studi Pendidikan Teknik Elektro. Sampel yang diambil terdiri dari 17 peserta didik untuk kelas eksperimen dan 17 peserta didik untuk kelas kontrol. Prosedur pengambilan sampel pada penelitian ini menggunakan teknik purposive sampling.

Pada penelitian ini, pendekatan yang digunakan adalah penelitian eksperimental menggunakan desain Control Group pretest-posttest. Pada kelas kontrol, peserta didik diberikan pre-test. Setelah itu diberi perlakuan menggunakan dengan menggunakan pembelajaran secara konvensional. Kemudian proses pembelajaran diakhiri dengan pos test. Pada kelas eksperimen, proses pembelajaran diberikan treatment dengan metode pembelajaran Group Investigation (GI) menggunakan WhatsApp Messenger sebagai Mlearning. Teknik pengumpulan data menggunakan metode observasi, dokumentasi, wawancara, angket, dan tes. 
Analisis data hasil tes yang digunakan untuk mengukur data kemampuan aspek pengetahuan peserta didik yang diperoleh dari pretest dan posttest berbentuk soal pilihan ganda. Peningkatan kemampuan ditinjau dari kemampuan berpikir kritis sebelum dan sesudah pembelajaran dihitung dengan rumus gain faktor (N-Gain). Uji prasyarat analisis dilakukan pada data pretest dan posttest peserta didik melalui uji normalitas dan homogenitas. Hasil dari uji prasyarat digunakan sebagai dasar pengujian lebih lanjut menggunakan uji t terhadap kemampuan berpikir kritis. Uji t (t-test) digunakan untuk membandingkan perbedaan metode pembelajaran yang diterapkan antara kelompok eksperimen dan kelompok kontrol. Hipotesis yang diajukan adalah ada perbedaan pengaruh penerapan metode Group Investigation (GI) dengan WhatsApp Messenger sebagai mobile learning terhadap kemampuan berpikir kritis.

\section{Hasil dan Pembahasan}

Tabel 1. Deskripsi Data Kemampuan Berpikir Kritis

\begin{tabular}{|c|c|c|c|c|c|c|c|}
\hline \multicolumn{8}{|c|}{ Group Statistics } \\
\hline & & $\mathrm{N}$ & Mean & Std. Deviation & $\begin{array}{l}\text { Std. } \\
\text { Error } \\
\text { Mean }\end{array}$ & Maximum & Minimum \\
\hline \multirow{2}{*}{ Test2 } & Control group & 17 & 74.29 & 4.10 & 0.99 & 85 & 69 \\
\hline & Experiment group & 17 & 79.41 & 6.41 & 1.55 & 90 & 71 \\
\hline
\end{tabular}

Tabel 1., memperlihatkan rata-rata kemampuan berpikir kritis pada masing-masing sampel berjumlah 17 peserta didik. Pada kelas kontrol menunjukkan rerata nilai sebesar 74,29, skor maksimum 85, dan skor minimum 69. Pada kelas eksperimen rerata nilai sebesar 79,41, skor maksimum 90, dan skor minimum 71.

Tabel 2. Uji Normalitas Kemampuan Berpikir Kritis

\begin{tabular}{|c|c|c|c|c|c|c|c|}
\hline \multicolumn{8}{|c|}{ Tests of Normality } \\
\hline & & \multicolumn{3}{|c|}{ Kolmogorov-Smirnov ${ }^{\mathrm{a}}$} & \multicolumn{3}{|c|}{ Shapiro-Wilk } \\
\hline & Kelas & Statistic & df & Sig. & Statistic & df & Sig. \\
\hline \multirow[t]{2}{*}{ Prestasi } & Kelas Eksperimen & .125 & 17 & $.200^{\star}$ & .963 & 17 & .683 \\
\hline & Kelas Kontrol & .196 & 17 & .080 & .899 & 17 & .066 \\
\hline
\end{tabular}

a. Lilliefors Significance Correction

*. This is a lower bound of the true significance.

Berdasarkan Tabel 2, diketahui hasil uji normalitas data kemampuan berpikir kritis pada kelas eksperimen maupun kelas kontrol diperoleh nilai signifikansi $\geq 0,05$ maka dapat diambil keputusan bahwa semua data pada kemampuan berpikir kritis berdistribusi normal. Uji normalitas dengan uji Kolmogorov-smirnov diperoleh signifikasi pada kelas eksperimen sebesar 0,200 dan kelas kontrol sebesar 0,080. 
Tabel 3. Uji Homogenitas Kemampuan Berpikir Kritis

\begin{tabular}{ll|c|c|c|c}
\hline \multicolumn{5}{c}{ Test of Homogeneity of Variance } \\
\hline \multirow{3}{*}{ Prestasi } & Levene Statistic & $\mathrm{df1}$ & $\mathrm{df2}$ & Sig. \\
& Based on Mean & 3.604 & 1 & 32 & .067 \\
\cline { 2 - 6 } & Based on Median & 2.968 & 1 & 32 & .095 \\
\cline { 2 - 6 } & $\begin{array}{l}\text { Based on Median and with } \\
\text { adjusted df }\end{array}$ & 2.968 & 1 & 30.486 & .095 \\
\cline { 2 - 6 } & Based on trimmed mean & 3.559 & 1 & 32 & .068 \\
\hline
\end{tabular}

Berdasarkan Tabel 3., uji homogenitas dengan uji Levene's diperoleh signifikasi kemampuan berpikir kritis untuk kelas eksperimen sebesar 0,067 yg lebih besar dari 0,05 maka dapat disimpulkan bahwa data kemampuan berpikir kritis siswa homogen.

Tabel 4. Uji Hipotesis Kemampuan Berpikir Kritis

\begin{tabular}{|c|c|c|c|c|c|c|c|c|c|c|}
\hline \multicolumn{11}{|c|}{ Independent Samples Test } \\
\hline & & \multicolumn{2}{|c|}{$\begin{array}{l}\text { Levene's } \\
\text { Test for } \\
\text { Equality of } \\
\text { Variances }\end{array}$} & \multicolumn{7}{|c|}{ t-test for Equality of Means } \\
\hline & & \multirow[t]{2}{*}{ 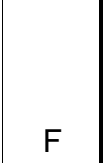 } & \multirow[b]{2}{*}{ Sig. } & \multirow[b]{2}{*}{$\mathrm{t}$} & \multirow[b]{2}{*}{ df } & \multirow{2}{*}{$\begin{array}{l}\text { Sig. (2- } \\
\text { tailed) }\end{array}$} & \multirow{2}{*}{$\begin{array}{c}\text { Mean } \\
\text { Differenc } \\
\mathrm{e}\end{array}$} & \multirow{2}{*}{$\begin{array}{c}\text { Std. Error } \\
\text { Differenc } \\
\mathrm{e}\end{array}$} & \multicolumn{2}{|c|}{$\begin{array}{l}95 \% \text { Confidence } \\
\text { Interval of the } \\
\text { Difference }\end{array}$} \\
\hline & & & & & & & & & Lower & Upper \\
\hline Prestasi & $\begin{array}{l}\text { Equal variances } \\
\text { assumed }\end{array}$ & 3.604 & .067 & 2.773 & 32 & .009 & 5.118 & 1.845 & 1.359 & 8.876 \\
\hline & $\begin{array}{l}\text { Equal variances } \\
\text { not assumed }\end{array}$ & & & 2.773 & $\begin{array}{r}27.2 \\
41\end{array}$ & .010 & 5.118 & 1.845 & 1.333 & 8.902 \\
\hline
\end{tabular}

Berdasarkan Tabel 4, uji perbandingan antara kedua kelas yang dilaksanakan dengan independent samples test memberikan nilai 0,009 lebih kecil dari 0,05 yang berarti hasil tidak sama. Uji perbandingan antara kedua kelas yang dilaksanakan memberikan nilai 0,007 lebih kecil dari 0,05 yang berarti hasil tidak sama. Hal ini berarti ada perbedaan kemampuan berpikir kritis antara kelas eksperimen dengan kelas kontrol.

\section{a. N-Gain}

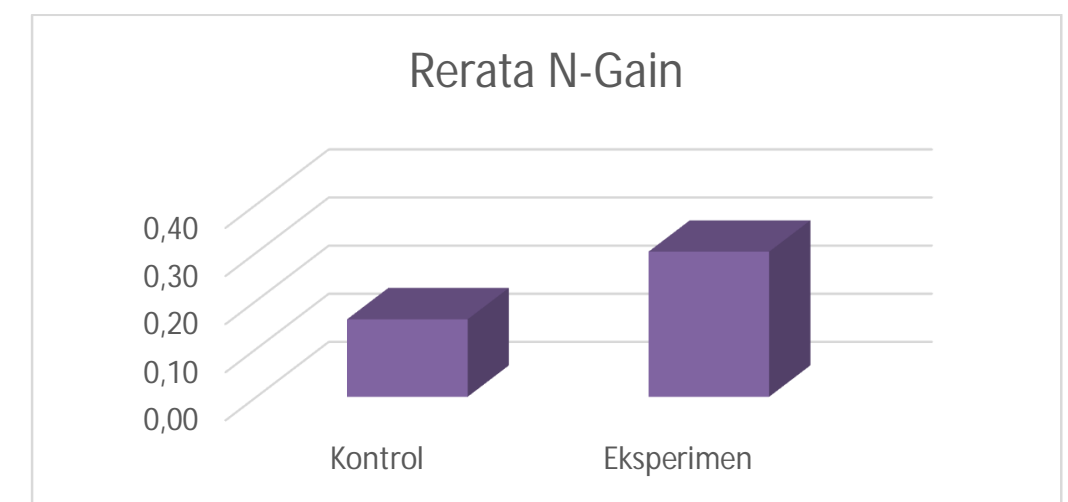

Gambar 1. Grafik Rerata Peningkatan Kemampuan Berpikir Kritis 
Gambar 7 di atas menunjukkan bahwa pada kelompok kontrol skor N-Gain menunjukkan nilai 0,16 yang menunjukkan peningkatan kemampuan berpikir kritis dalam kategori rendah. Sedangkan pada kelompok eksperimen skor $\mathrm{N}$-Gain menunjukkan nilai 0,30 yang menunjukkan peningkatan kemampuan berpikir kritis dalam kategori sedang. Jadi dapat disimpulkan bahwa rerata kemampuan berpikir kritis peserta didik (N-Gain) kelas eksperimen lebih tinggi dibandingkan dengan rata-rata kemampuan berpikir kritis siswa (N-Gain) kelas kontrol.

\section{b. Pembahasan}

Pengaruh yang positif dari metode pembelajaran yang diterapkan juga pada kemampuan berpikir kritis peserta didik. Penilaian tes kemampuan berpikir kritis mengacu pada hasil pre test dan pos tes. Setelah data dinyatakan normal dan homogen, maka dilanjutkan dengan independent samples test antara kelas eksperimen dengan kelas kontrol. Hasil uji $\mathrm{t}$ menunjukkan bahwa ada perbedaan anatara kelas eksperimen dan kelas kontrol. Berdasarkan nilai rerata pada Tabel 2., kelas eksperimen memiliki nilai rata-rata lebih tinggi dibandingkan kelas kontrol. Hal ini menunjukkan bahwa kemampuan berpikir kritis peserta didik menggunakan WhatsApp Messenger terintegrasi metode pembelajaran Group Investigation lebih baik daripada kelas kontrol.Metode pembelajaran ini memiliki keunggunalan melatih peserta didik untuk membangun kemampuan berfikir secara mandiri dan kritis serta melatihnya dalam menyelesaikan suatu permasalahan dalam kelompok. Model pembelajaran GI menurut Slavin (2010:216-229) yaitu setiap tahapan dalam model pembelajaran tersebut mengarahkan peserta didik untuk berpikir kritis. Oleh karena itu, dalam penelitian ini kemampuan berpikir kritis dikembangkan dalam upaya meningkatkan hasil belajar.

Efektifitas penerapan pembelajaran WhatsApp Messenger terintegrasi metode pembelajaran Group Investigationterlihat dari uji skor N-Gain. Pada kelompok eksprimen skor N-Gain menunjukkan nilai 0,30 yang menunjukkan peningkatan kemampuan berpikir kritis dalam kategori sedang. Sedangkan pada kelompok kontrol skor N-Gain menunjukkan nilai 0,16 yang menunjukkan peningkatan kemampuan berpikir kritis dalam kategori rendah. Sejalan dengan penelitian Winda dkk (2015), keterlaksanaan model pembelajaran kooperatif tipe Group Investigation dirancang untuk melatihkan keterampilan berpikir kritis. Peserta dididik terlatih untuk berpikir bersama kelompok namun dengan tanggungjawab individu untuk berinvestigasi membahas masalah yang dihadapi. Stimulus dalam kelompok, dibuat untuk memancing daya nalar dan kemampuan berpikir kritis dari anggota. Kerjasama dalam kelompok yang heterogen akan mendapat penghargaan dari pendidik berdasarkan skor perbaikan permasalahan dari kelompok maupun individu. Melalui penghargaan ini, peserta didik akan termotivasi belajar dan berpikir menemukan jawaban dari setiap masalah yang diberikan. Hal tersebut tentunya didukung dengan teknologi WhatsApp Messengersehingga peserta didik dapat berinteraksi, secara terbuka menyampaikan pendapat, dan memperoleh jawaban dari setiap permasalahan dengan cepat.

Berdasarkan hasil angket terhadap metode pembelajaran yang diterapkan, secara umum menunjukkan ketertarikan. Seperti pada Gambar 8 berikut. 


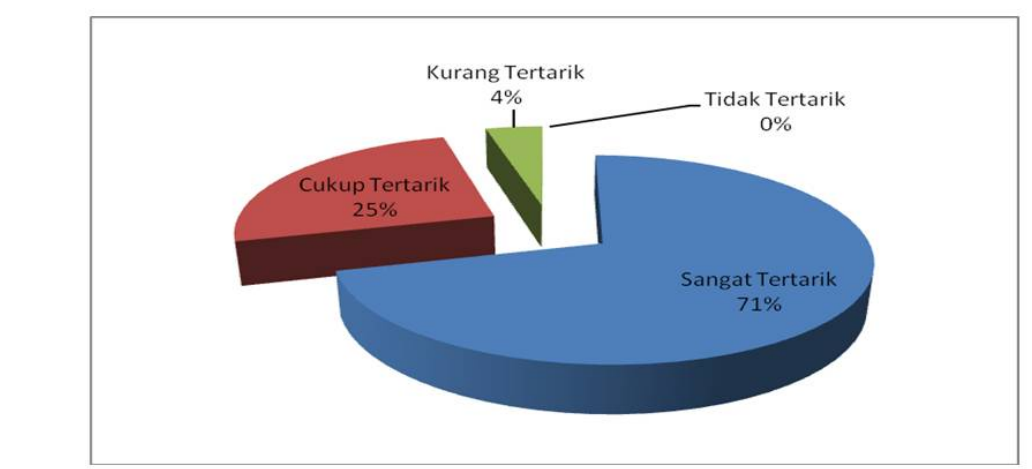

Gambar 2. Diagram lingkaran yang menunjukkan persentase ketertarikan siswa

Gambar 2 menunjukkan bahwa $71 \%$ dari 17 siswa pada kelas menyatakan sangat tertarik terhadap metode pembelajaran Group Investigation terintegrasi WhatsApp Messenger, $25 \%$ siswa menyatakan cukup tertarik, $4 \%$ siswa menyatakan kurang tertarik, dan tidak ada siswa yang tidak tertarik.

\section{Kesimpulan dan Saran}

Hasil penelitian menunjukkan bahwa penggunaan Whatsapp Messenger sebagai mobile learning terintegrasi metode group investigation efektif untuk diterapkan dalam proses pembelajaran dalam upaya meningkatkan kemampuan berpikir kritis peserta didik. Desain pembelajaran yang dilakukan meliputi start, grouping, planning, presenting, organizing, investigating, evaluating, ending.Kemampuan berpikir secara mandiri dan kritis dapat dilatih melalui kegiatan menginvestigasi suatu permasalaha dalam kelompok. Secara keseluruhan, siswa tertarik dan termotivasi mengikuti pembelajaran dengan menggunakan WhatsApp dikombinasikan dengan metode investigation.

Pada penelitian yang lebih lanjut, derlu dilakukan pengembangan model pembelajaran yang terintegrasi media sosial dalam upaya meningkatkan kemampuan peserta didik. Integrasi dengan media sosial ini penting mendapat perhatian seiring perkembangannya yang sangat signifikan.

\section{Daftra Pustaka}

[1] Hendrik P., Nunus W. 2016. Pengaruh Penggunaan Macromedia Sebagai Media Pembelajaran Pada Standar Kompetensi Instalasi Video Game Di SMK Gamaliel 1 Madiun. JUPITER (Jurnal Pendidikan Teknik Elektro), 1 (1), 35-40.

[2] Lillian, B. 2012. Scaffolding Teachers Integrate Social Media Into a Problem-Based Learning Approach. The Electronic Journal of e-Learning, 10 (1), 13-22.

[3] Slavin, R. E. 2010. Cooperatif Learning: Teori, Riset dan Praktik. Bandung: Nusa Media.

[4] Winda, Miraningsih, dkk. 2015. Penerapan Model Pembelajaran Kooperatif Tipe Group Investigation Untuk Melatihkan Keterampilan Berpikir Kritis Siswa Pada Materi Pokok Asam Basa Kelas Xi Mia Sman 2 Magetan. UNESA Journal of Chemical Education, 4 (2), 281-287 